\title{
EFFECT OF FEED RESTRICTION OF LAYING JAPANESE QUAIL UNDER NORTH SINAI CONDITIONS. 2- ON EGG PRODUCTION
}

\author{
Ali, A. M.; M. M. Shetaewi; K. I. Said and A. R. Roshdy \\ Dept. of Animal Production, Fac.of Environmental Agric. Sciences, Suez \\ Canal Univ.
}

\begin{abstract}
This experiment was conducted to investigate the effect of feed restriction on egg production of laying Japanese quail during the period from 6 to 14 wk of age. Four hundred and fifty Japanese quail chicks were divided into five groups. Each treatment group contained three replicates of 30 birds (20 females +10 males) each. Layers were reared in brooder batteries. Treatments were assigned as follows:. T1, layers fed $100 \%$ of daily feed intake requirement (control) T2, layers fed $90 \%$ of daily feed intake requirements, T3, layers fed $80 \%$ of daily feed intake requirements, T4, layers fed $70 \%$ of daily feed intake requirements and T5, layers fed $60 \%$ of daily feed intake requirements. Feed intake, egg number and egg weight were recorded. Egg mass and feed conversion ( $g$ feed / $g$ egg mass ) were then calculated.

Results showed that increasing feed restriction negatively affected $(P<0.01)$ body weight compared with the control. At the age of $6 \mathrm{wk}$, hens receiving 80,70 and $60 \%$ of the recommended feed intake laid no eggs, while at wk 7 , hens that received $60 \%$ feed intake still laid no eggs. However, hens fed $90 \%$ of the recommended feed intake quail eggs equal $(P<0.05)$ to that of the control group. Egg mass values trended to agree with both egg number and egg weight as expected. Birds subjected to severe feed restriction in early life showed lower quality of albumin and yolk compared to those given feed ad libitum. Total economic costs declined as the level of restriction increased. Net revenue, economical efficiency and relative economic efficiency values were lower in treatment groups except the group of birds fed $90 \%$ of the requirements as they showed higher values and surpassed the ad lib control one .
\end{abstract}

Keywords: Japanese quail hens, restriction, egg production

\section{INTRODUCTION}

Feed restricted birds are hyperactive, and the pace of activity increases before the expected feeding time. There water intake increases and pecking of non-food objects increases too, compared with ad libitum fed birds (Kostal et al, 1992; Savory et al, 1992). Feed restriction during rearing period stimulates sexual maturity in around the same age and body size of ad lib-fed birds. The timing of growth of the reproductive tract might be influenced by certain nutrients and / or feeding regimens. Lee et al., (1971) reported that applying feed restriction delayed sexual maturity which is thereafter reflected on the higher production of eggs and greater egg size.

Johnson et al., (1985) proposed that feed intake prior to first egg production was the main determinant for onset of lay. Several authors considered age at first egg as the set point for egg production (Dunnington and Siegel, 1984), whereas others contemplated age at $10 \%$ production (Gous and Stielau, 1976 and Gous, 1978) or age at 50\% production (AbuSerewa, 1979; Wells, 1980; Mbugua and Cunningham, 1983) as a reliable estimate for onset of lay. 


\section{Ali, A. M. et al}

The mean age at sexual maturity was influenced by the date of release from food restriction Gous et al., (2000) found that food restriction has an effect on the age of maturity in laying hens. The length of time between the release from food restriction to the onset of lying depends on the age of the pullets when the release occurred.

Mean egg weight was $4 \mathrm{~g}$ heavier at 22 wks of age in birds released from food restriction at 16 and $18 \mathrm{wks}$, than from those released at 24 and 26 wks of age. However, by 30 wks of age, birds restricted for longer periods produced heavier eggs than their earlier-maturing counterparts. This effect continued until the end of the trial at $40 \mathrm{wks}$ of age, at which time there was a 2-3 g difference in egg weight between these treatments on pullets (Gous et al., 2000). They showed that egg weight at a given age was significantly affected by the age at release from food restriction. That restricting food intake reduces egg weight is not surprising. What is of interest is that egg weight, after lifting food restriction, increases beyond that of eggs produced by birds whose food had not been restricted for as long a period.

Hassan et al.,( 2003) reported that body weight at first egg was significantly heavier for females fed $70 \%$ of ad libitum than for birds on other treatments. Fertility, age at first egg, feed conversion, egg production, and egg weight were not affected by feed restriction. Although hatchability was not affected by feed restriction, percentage of late dead and total dead embryos were significantly reduced in eggs from restricted quail. Quail fed $70 \%$ of ad libitum intake had significantly increased egg specific gravity. The authors stated that feed can be restricted to 85 or $70 \%$ of ad libitum feed intake from 2 to $5 \mathrm{wk}$ of age without detrimentally affecting reproductive parameters between 6 to $13 \mathrm{wk}$ of age.

This study was conducted to investigate the effect of feed restriction $(90,80,70$, and $60 \%$ of daily feed intake requirements) on egg production of laying Japanese quail during the period from 6 to 14 week of age under North Sinai conditions.

\section{MATERIALS AND METHODS}

The present work was conducted at Animal Production Department, Faculty of Environmental Agriculture Sciences, El-Arish, North Sinai, Suez Canal University, Egypt, during the period from February to November 2004.

\section{Birds and treatments:}

A total number of 450 Japanese quail hens were divided into five groups, each of 90 males and females. Each treatment group contained three replicates of 30 birds ( 20 females +10 males). Layers were reared in brooder batteries. Treatments were as follows: - T1,layers fed $100 \%$ of daily feed intake requirements (control), T2, layers fed $90 \%$ of daily feed intake requirements, T3 layers fed $80 \%$ of daily feed intake requirements, T4, layers fed $70 \%$ of daily feed intake requirements and T5, layers fed $60 \%$ of daily feed intake requirements.

All birds were kept in the same managerial conditions. The basal diet was formulated to cover the recommended levels of all nutrients needed for laying Japanese quail ( Table 1). 
Table (1) Composition and calculated analysis of basal diet.

\begin{tabular}{|l|c|}
\hline Ingredient & $\%$ \\
\hline Yellow corn & 61.500 \\
\hline Soybean meal (44\%) & 20.60 \\
\hline Corn gluten meal (60\%) & 2.400 \\
\hline Limestone & 4.400 \\
\hline Sodium chloride & 0.250 \\
\hline Premix * & 0.250 \\
\hline Protein concentrate & 10.000 \\
\hline Di-calcium-phosphate & 0.595 \\
\hline DL-methionine & 0.005 \\
\hline Total & 100.00 \\
\hline Calculated analysis : & \\
\hline Crude protein (CP)\% & 20.770 \\
\hline ME Kcal/Kg diet & 2854.100 \\
\hline Ether extract (EE)\% & 6.022 \\
\hline Calcium \% & 2.571 \\
\hline Total P \% & 0.705 \\
\hline Available P \% & 0.382 \\
\hline Methionine \% & 0.452 \\
\hline Lysine \% & 1.005 \\
\hline Methionine + Cystine \% & 0.789 \\
\hline Cost for Kg (L.E.) & 1.51 \\
\hline
\end{tabular}

* Each kilogram of contains = Vit. A, 12000 I.U.; Vit. D3, 2000 I.U.; Vit. E, 10mg.; Vit. K3, 2mg.; Vit. B1, 1mg.; Vit. B2, 5mg.; Vit. B6, 1.5mg.; Vit. B12, 0.01mg.; Niacin acid, 30mg.; Pantothenic acid,10mg.; Folic acid, 1mg.; Biotin, 0.05mg.; Choline chloride, 260mg.; Iron, 30mg.; Copper, 10mg.; Zinc, 50mg.; Manganese, 60mg.; lodine, 1mg.; Selenium, $0.1 \mathrm{mg}$. and $0.1 \mathrm{mg}$. Cobalt.

** Pro.concentrate : Cp,48\%.; ME,2450 kcal/kg .; Ca,7\%.; A.P2.6\%.; lysine 2.3\% .; Methionine $1.44 \%$.; Methionine + Cystine $2.2 \%$.

${ }^{\star * \star}$ According to NRC(1994)

\section{Management:}

Throughout the experimental period, all treatments were kept under the same conditions. The birds were daily provided with their feed as previously mentioned for each treatment and water was provided ad libitum. Standard and recommended light regime was applied throughout the experimental period which is durated from 6 to 14 weeks of age.

\section{Methods of interpreting results}

Feed intake, egg number and egg weight were recorded. Egg mass and feed conversion

( $g$ feed / g egg mass ) were calculated. Egg quality was estimated for experimental birds every four weeks at wk 10 and 14 after sexual maturity till the end of the experiment at 14 wks old. Egg shape index was calculated by dividing the transverse diameter of egg by the longitudinal one using Johansson and Randel (1968) formula:

$\mathrm{SI}=$ (Egg width / Egg length) $\times 100$

Albumen weight $(\mathrm{g})$ was calculated as egg weight - (Yolk weight + Shell weight) and albumen height $(\mathrm{mm})$ was determined using a calliper. Haugh unit score (HU) was calculated according to (Silversides, 1994) using the formula: 
$H U=100 \log \left(H+7.57-1.7 W^{0.37}\right)$

where : $\mathrm{H}=$ Albumen height $(\mathrm{mm}), \mathrm{W}=$ Egg weight $(\mathrm{g})$

Yolk quality included yolk weight (gm), percent, and yolk shape index.

Yolk shape index (YSI) was calculated according to (Sharp, 1929) using the formula:

YSI $=$ (Yolk height / Yolk diameter $) \times 100$

Shell quality includes shell weight $(g)$, percent, thickness $(\mu)$. Shell thickness was measured as an average of two measurements of thickness from the mid section of the egg after removing the membranes, using micrometer caliper (Johansson and Rendel 1968).

Accumulative mortality rate was calculated throughout all experimental period by subtracting number of live birds at the end of each period from the total number of birds at the beginning of the same period.

\section{Economic evaluation of the experimental treatments:}

Economic evaluation of dietary treatments was represented by the feed cost needed to obtain one unit egg of production.

Statistical analysis:

Data were analyzed by analysis of variance procedures using General linear Models ( GLM) procedure of SAS (1990). Differences among treatment means were separated by Duncan's Multiple Range Test (Duncan, 1955).

\section{RESULTS AND DISCUSSION}

\section{Live body weight:}

The actual aim of this study was to find-out if there are an effect of early life feed restriction on body weight and egg production of quail hens during the period from 6 to 14 weeks of age.

Data in Table 2 shows the average body weight of mixed (unsexed) birds from 6 to 14 weeks of age.

Table 2. Means \pm SE of body weight from 6 to 14 weeks old for Japanese quail raised under feed restriction regimens.

\begin{tabular}{|c|c|c|c|c|c|c|}
\hline $\begin{array}{l}\text { Treat. } \\
\text { Week }\end{array}$ & T1 & T2 & T3 & T4 & T5 & Sig. \\
\hline 6 & $192.44^{\mathrm{a}} \pm 7.92$ & $189.62^{\mathrm{a}} \pm 7.12$ & $176.73^{\circ} \pm 5.03$ & $161.38^{c} \pm 3.11$ & $146.19^{a} \pm 5.77$ & $\star \star$ \\
\hline 7 & $197.18^{\mathrm{a}} \pm 7.21$ & $201.64^{\mathrm{a}} \pm 7.90$ & $191.02^{\mathrm{D}} \pm 7.43$ & $179.35^{c} \pm 4.81$ & $162.43^{\mathrm{a}} \pm 7.57$ & ** \\
\hline 8 & $214.31^{a} \pm 8.95$ & $213.89^{\mathrm{a}} \pm 8.11$ & $202.93^{\mathrm{D}} \pm 8.02$ & $192.16^{\mathrm{c}} \pm 7.29$ & $170.81^{a} \pm 4.22$ & $\star \star$ \\
\hline 9 & $220.21^{\mathrm{a}} \pm 6.94$ & $216.34^{\mathrm{a}} \pm 6.87$ & $207.55^{\mathrm{a}} \pm 7.15$ & $192.23^{\mathrm{D}} \pm 5.38$ & $177.68^{\mathrm{D}} \pm 6.91$ & ** \\
\hline 10 & $222.19^{\mathrm{a}} \pm 6.65$ & $226.18^{\mathrm{a}} \pm 8.04$ & $214.28^{\mathrm{a}} \pm 4.43$ & $194.81^{\mathrm{D}} \pm 2.24$ & $191.59^{\circ} \pm 6.38$ & ** \\
\hline 11 & $214.41^{\mathrm{a}} \pm 5.07$ & $217.27^{a} \pm 5.35$ & $213.49^{\mathrm{a}} \pm 4.62$ & $200.77^{0} \pm 2.84$ & $193.53^{\circ} \pm 6.02$ & ** \\
\hline 12 & $206.40^{\mathrm{aD}} \pm 6.60$ & $207.85^{\mathrm{ab}} \pm 4.31$ & $212.09^{\mathrm{a}} \pm 5.35$ & $205.97^{\mathrm{a} o} \pm 4.34$ & $194.53^{\circ} \pm 6.23$ & $\star \star$ \\
\hline 13 & $05 \pm 10.85$ & $207.84 \pm 4.43$ & $211.71 \pm 3.59$ & $211.81 \pm 4.42$ & $206.18 \pm 7.82$ & Ns \\
\hline 14 & $196.25 \pm 14.87$ & $197.93 \pm 11.41$ & $199.79 \pm 15.69$ & $199.58 \pm 11.09$ & $197.50 \pm 12.75$ & Ns \\
\hline
\end{tabular}

T1= (control) birds received $100 \%$ of daily feed intake requirements,

T2= birds received $90 \%$ of daily feed intake requirements,

T3= birds received $80 \%$ of daily feed intake requirements,

T4= birds received $70 \%$ of daily feed intake requirements and

T5= birds received $60 \%$ of daily feed intake requirements.

$\mathrm{a}, \mathrm{b}, \ldots=$ Means on the same row with different letters are differ significantly $(\mathrm{P}<0.05)$

NS= insignificant differences $(P>0.05)$,

${ }^{* *}=$ highly significant differences $(P<0.01)$ 
The obtained data indicate that until week 12 there was still an effect on body weight due to early life feed restriction. At week13 and 14, there were no significant $(P<0.05)$ differences on body weight among treatments. These findings are in good agreement with Kwakkel et al., (1993). However, Brody et al., (1980) and Fattori et al.,(1991) speculated that body weight could be compensated after period of feed restriction and this recovering is mainly dependent on strain, age, period of restriction, level of restriction and dietary nutrient contents mainly ME and crude protein.

\section{Egg production:}

\section{Egg number:}

Data on egg production are presented in Table 3. Data on weekly egg number indicated that there were highly significant differences among treatments concerning the feed restriction applied. At week 6 , there were no eggs in T3, T4 and T5 (birds received 80,70 and $60 \%$ of the recommended feed intake), respectively and at week 7 there were no eggs in T5 (birds received $60 \%$ of the recommended). Till week 11, the significances $(P<0.01)$ were presented while after week 11 , these differences were disappeared. The weekly egg number were commonly similar among treatments after week 11 except in week 14 in which there were highly significant $(P<0.01)$ differences among treatments. While, for the overall period (6-14 weeks), total egg number showed highly significant $(P<0.01)$ differences, where the values were linearly declined by increasing the level of restriction. This is in agreement with the finding of Bruggeman et al., (1999) who demonstrated that, the effects of restricted feeding during rearing were carried over to the laying period with clear effects on the functioning of the reproductive axis (egg production)

Table 3. Means \pm SE of egg number per hen from 6 to 14 weeks old for Japanese quail raised under feed restriction regimens.

\begin{tabular}{|c|c|c|c|c|c|c|}
\hline Week $\quad$ Treat. & T1 & T2 & T3 & T4 & T5 & Sig. \\
\hline 6 & $0.53^{a} \pm 0.02$ & $0.22^{b} \pm 0.05$ & $0.00^{c} \pm 0.00$ & $0.00^{c} \pm 0.00$ & $0.00^{c} \pm 0.00$ & $\star \star$ \\
\hline 7 & $3.34^{a} \pm 0.45$ & $3.58^{a} \pm 0.34$ & $1.18^{\mathrm{b}} \pm 0.36$ & $0.08^{c} \pm 0.08$ & $0.00^{c} \pm 0.00$ & ** \\
\hline 8 & $4.91^{a} \pm 0.31$ & $5.16^{a} \pm 0.47$ & $3.42^{\mathrm{b}} \pm 0.43$ & $1.09^{c} \pm 0.46$ & $0.03^{c} \pm 0.03$ & $* *$ \\
\hline 9 & $5.33^{a} \pm 0.29$ & $6.03^{a} \pm 0.24$ & $4.95^{a} \pm 0.94$ & $2.69^{b} \pm 0.71$ & $0.54^{c} \pm 0.29$ & ** \\
\hline 10 & $5.23^{a} \pm 0.76$ & $5.31^{a} \pm 0.35$ & $5.07^{a} \pm 0.78$ & $2.90^{\mathrm{b}} \pm 0.18$ & $1.48^{\mathrm{b}} \pm 0.58$ & ** \\
\hline 11 & $5.73^{a} \pm 0.74$ & $6.52^{a} \pm 0.37$ & $6.26^{a} \pm 0.17$ & $5.28^{a} \pm 0.35$ & $3.35^{b} \pm 0.68$ & ** \\
\hline 12 & $4.93 \pm 0.55$ & $4.85 \pm 0.56$ & $5.97 \pm 0.09$ & $5.77 \pm 0.34$ & $5.79 \pm 0.12$ & NS \\
\hline 13 & $5.93 \pm 0.14$ & $5.87 \pm 0.35$ & $5.53 \pm 0.27$ & $5.30 \pm 0.18$ & $5.89 \pm 0.27$ & Ns \\
\hline 14 & $5.98^{a} \pm 0.11$ & $5.20^{\mathrm{ab}} \pm 0.12$ & $4.40^{b} \pm 0.52$ & $5.56^{a} \pm 0.30$ & $6.10^{a} \pm 0.24$ & ** \\
\hline 6-14 & $4.66^{a} \pm 0.20$ & $4.75^{\mathrm{a}} \pm 0.13$ & $4.09^{b} \pm 0.24$ & $3.19^{c} \pm 0.18$ & $2.58^{d} \pm 0.13$ & ** \\
\hline Total & $41.91^{\mathrm{a}} \pm 1.80$ & $42.73^{a} \pm 1.17$ & $36.80^{\mathrm{b}} \pm 2.15$ & $28.67^{c} \pm 1.59$ & $23.18^{d} \pm 1.13$ & $\star \star$ \\
\hline
\end{tabular}

$\mathrm{T} 1=$ (control) birds received $100 \%$ of daily feed intake requirements,

T2= birds received $90 \%$ of daily feed intake requirements,

$\mathrm{T} 3=$ birds received $80 \%$ of daily feed intake requirements,

T4= birds received $70 \%$ of daily feed intake requirements and

$\mathrm{T} 5=$ birds received $60 \%$ of daily feed intake requirements.

$a, b, \ldots=$ Means on the same row with different letters are differ significantly $(P<0.05)$

NS= insignificant differences $(P>0.05)$

${ }^{\star *}=$ highly significant differences $(P<0.01)$ 
Present data are confirming the finding of Morris (1985)and Hocking (1993) who concluded that feed restriction should be continued until the onset of lay because multiple ovulations are a major source of lost of egg production when they are not reduced from week 15 of age onward.

\section{Egg weight:}

Table (4) illustrated the obtained results on egg weight. The values of egg weight appeared that there were no significant $(P>0.05)$ differences due to feed restriction except on the first 3 weeks of production in which egg weight is negatively affected $(P>0.01)$ by feed restriction regimens. It is wise to notice that egg weight, throughout all treatments is increasing from week 6 till week 9 thereafter it becomes approximately around 10 to $11 \mathrm{gm}$. The results obtained herein are in good conduction with those of Fattori et al., (1991). In this connection, Gous et al., (2000) reported that egg weight is affected by age; and feed restriction in early life did not affect significantly the common average egg weight. In physiological point of view, the hen lay egg when complete the egg formation accordingly, it may take less or more time but anyhow will lay it when its reached the optimal composition and formation which mainly related to strain, age, environmental conditions and balanced diet. These facts are allocated in the resultant reported by Zelenka et al., (1987) and katanbaf et al., (1989b).

Table 4. Means \pm SE of average egg weight from 6 to 14 weeks old for Japanese quail raised under feed restriction regimens.

\begin{tabular}{|c|c|c|c|c|c|c|}
\hline Week $\quad$ Treat. & T1 & T2 & T3 & T4 & T5 & Sig. \\
\hline 6 & $8.75^{a} \pm 0.86$ & $8.23^{a} \pm 0.58$ & $0.00^{\mathrm{b}} \pm 0.00$ & $0.00^{b} \pm 0.00$ & $0.00^{\mathrm{b}} \pm 0.00$ & ** \\
\hline 7 & $9.57^{a} \pm 0.15$ & $9.95^{\mathrm{a}} \pm 0.22$ & $9.93^{a} \pm 0.29$ & $3.09^{b} \pm 3.09$ & $0.00^{\mathrm{b}} \pm 0.00$ & ** \\
\hline 8 & $10.49^{\mathrm{a}} \pm 0.28$ & $10.86^{\mathrm{a}} \pm 0.18$ & $10.38^{\mathrm{a}} \pm 0.17$ & $10.34^{\mathrm{a}} \pm 0.23$ & $2.90^{b} \pm 2.90$ & ** \\
\hline 9 & $11.11 \pm 0.23$ & $11.35 \pm 0.09$ & $10.84 \pm 0.18$ & $10.66 \pm 0.24$ & $10.34 \pm 0.48$ & NS \\
\hline 10 & $11.30 \pm 0.09$ & $11.36 \pm 0.18$ & $11.11 \pm 0.21$ & $10.85 \pm 0.26$ & $10.93 \pm 0.16$ & NS \\
\hline 11 & $11.01 \pm 0.16$ & $11.60 \pm 0.17$ & $10.93 \pm 0.31$ & $10.57 \pm 0.09$ & $10.8 \pm 0.16$ & NS \\
\hline 12 & $11.31 \pm 0.08$ & $11.44 \pm 0.18$ & $11.16 \pm 0.40$ & $11.57 \pm 0.32$ & $11.29 \pm 0.06$ & NS \\
\hline 13 & $11.23 \pm 0.18$ & $11.26 \pm 0.38$ & $11.38 \pm 0.41$ & $11.58 \pm 0.18$ & $11.17 \pm 0.19$ & NS \\
\hline 14 & $11.33^{\mathrm{ab}} \pm 0.30$ & $11.10^{\mathrm{a}} \pm 0.11$ & $11.31^{\mathrm{ab}} \pm 0.38$ & $11.73^{\mathrm{ab}} \pm 0.01$ & $11.91^{b} \pm 0.13$ & NS \\
\hline
\end{tabular}

T1= (control) birds received $100 \%$ of daily feed intake requirements,

T2= birds received $90 \%$ of daily feed intake requirements,

T3= birds received $80 \%$ of daily feed intake requirements,

T4= birds received $70 \%$ of daily feed intake requirements and

T5= birds received $60 \%$ of daily feed intake requirements.

$\mathrm{a}, \mathrm{b}, \ldots=$ Means on the same row with different letters are differ significantly $(P<0.05)$

NS= insignificant differences $(P>0.05)$,

${ }^{* *}=$ highly significant differences $(P<0.01)$

\section{Egg mass:}

Table (5) illustrated the obtained results on egg mass. Egg mass values logically trended with both egg number and egg weight. In the present study, egg mass values recorded similar trend as that of egg number. This refers to the changes in egg number related to experimental feed restriction treatments applied. Moreover, egg mass as an important industrial and 
economical record could be used as an indicator for recovering time length after feed restriction.

Table 5. Means \pm SE of average egg mass from 6 to 14 weeks old for Japanese quail raised under feed restriction regimens.

\begin{tabular}{|c|c|c|c|c|c|c|}
\hline Week & T1 & T2 & T3 & T4 & T5 & Sig. \\
\hline 6 & $4.68^{a} \pm 0.52$ & $1.82^{b} \pm 0.48$ & $0.00^{c} \pm 0.00$ & $0.00^{c} \pm 0.00$ & $0.00^{c} \pm 0.00$ & $* *$ \\
\hline 7 & $31.98^{a} \pm 4.24$ & $35.49^{a} \pm 2.79$ & $11.91^{b} \pm 4.01$ & $0.77^{c} \pm 0.77$ & $0.00^{c} \pm 0.00$ & ** \\
\hline 8 & $51.30^{a} \pm 2.05$ & $55.92^{\mathrm{a}} \pm 4.18$ & $35.59^{b} \pm 4.92$ & $11.26^{c} \pm 4.72$ & $0.26^{c} \pm 0.26$ & ** \\
\hline 9 & $59.29^{a} \pm 3.97$ & $68.50^{\mathrm{a}} \pm 2.67$ & $53.38^{a} \pm 9.49$ & $28.57^{b} \pm 7.49$ & $5.73^{c} \pm 3.09$ & $\star \star$ \\
\hline 10 & $59.09^{a} \pm 8.40$ & $60.38^{a} \pm 4.75$ & $56.17^{\mathrm{a}} \pm 8.23$ & $31.52^{b} \pm 2.63$ & $16.08^{\mathrm{b}} \pm 6.19$ & ** \\
\hline 11 & $62.90^{\mathrm{ab}} \pm 7.44$ & $75.65^{\mathrm{a}} \pm 4.99$ & $68.43^{\mathrm{ab}} \pm 1.99$ & $55.83^{\mathrm{b}} \pm 4.18$ & $36.27^{\mathrm{c}} \pm 7.74$ & ** \\
\hline 12 & $55.73 \pm 6.18$ & $55.4 \pm 6.13$ & $66.59 \pm 1.37$ & $66.60 \pm 3.50$ & $65.35 \pm 1.21$ & NS \\
\hline 13 & $66.63 \pm 2.70$ & $65.78 \pm 1.81$ & $62.78 \pm 1.91$ & $61.34 \pm 1.11$ & $65.79 \pm 3.40$ & NS \\
\hline 14 & $67.82^{\mathrm{ab}} \pm 3.11$ & $57.71^{\mathrm{bc}} \pm 1.11$ & $50.01^{c} \pm 7.17$ & $65.20^{\mathrm{ab}} \pm 3.49$ & $72.62^{\mathrm{a}} \pm 2.19$ & * \\
\hline 6-14 & $51.05^{\mathrm{a}} \pm 1.77$ & $52.96^{a} \pm 0.92$ & $44.98^{\mathrm{b}} \pm 1.60$ & $35.68^{c} \pm 1.68$ & $29.12^{d} \pm 1.37$ & ** \\
\hline Total & $459.42^{\mathrm{a}} \pm 15.96$ & $476.66^{a} \pm 8.25$ & $404.85^{b} \pm 14.37$ & $321.09^{c} \pm 15.11$ & $262.11^{d} \pm 12.35$ & $* *$ \\
\hline
\end{tabular}

$\mathrm{T} 1=$ (control) birds received $100 \%$ of daily feed intake requirements,

T2= birds received $90 \%$ of daily feed intake requirements,

T3= birds received $80 \%$ of daily feed intake requirements,

T4= birds received $70 \%$ of daily feed intake requirements and

T5= birds received $60 \%$ of daily feed intake requirements.

$\mathrm{a}, \mathrm{b}, \ldots=$ Means on the same row with different letters are differ significantly $(P<0.05)$

NS= insignificant differences $(P>0.05),{ }^{*}=$ significant differences $(P<0.05)$ and ${ }^{* \star}=$ highly significant differences $(P<0.01)$

\section{Egg quality:}

Data on external and internal egg quality are presented in Table 6 and 7 for hens at week 10 and 14 of age, respectively. These two times of measuring egg quality were chosen to provide the effect of feed restriction before (10 weeks) and after (14 weeks) recovering from the early life feed restriction.

Obtained results show that egg weight was affected significantly $(\mathrm{P}<0.05)$ by feed restriction at week 10 , while at week 14 these affects were disappeared.

\section{External egg measurements:}

In both measuring times, the measurements of external egg parameters (Table 6) showed no significant differences among treatments with one exception. This exception is the egg longitudinal axis. This axis was significantly $(P>0.05)$ higher for hens fed either $100 \%$ or $90 \%$ of the recommended at week 10 and significantly $(P>0.05)$ higher for sever feed restricted hens at week 14 . Besides, sampling effect and time of laying, these phenomena can be considered as an outcome of statistical analysis, while in our opinion there is not scientific explanation for these values. Other external measurements such as egg width axis, egg shape index, and shell weight and thickness showed slight differences among treatments but these differences did not reach to be significant. This may confirm that the basics of the stress could mainly affect the egg production not the external egg measurements. While, once the egg completed the hen will lay it. This can be 
true if there are no change in nutrient, heat exposure, disease stress and some other factors.

Table 6. Means \pm SE of external and internal egg quality measurements at week 10 of age for Japanese quail raised under feed restriction regimens.

\begin{tabular}{|c|c|c|c|c|c|c|}
\hline Variable & T1 & T2 & T3 & T4 & T5 & Sig. \\
\hline \multicolumn{7}{|c|}{ External Egg measurements } \\
\hline Egg weight $(\mathrm{g})$ & $11.09^{\mathrm{ab}} \pm 0.24$ & $11.60^{a} \pm 0.23$ & $10.43^{\mathrm{b}} \pm 0.32$ & $11.14^{\mathrm{ab}} \pm 0.25$ & $10.52^{\mathrm{b}} \pm 0.27$ & * \\
\hline $\begin{array}{l}\text { Egg longitudinal axis } \\
(\mathrm{mm})\end{array}$ & $33.07^{a} \pm 0.33$ & $33.41^{\mathrm{a}} \pm 0.29$ & $31.68^{\mathrm{b}} \pm 0.26$ & $32.51^{\mathrm{ab}} \pm 0.58$ & $32.47^{\mathrm{ab}} \pm 0.58$ & * \\
\hline Egg width axis (mm) & $25.77 \pm 0.19$ & $26.18 \pm 0.12$ & $25.71 \pm 0.20$ & $25.99 \pm 0.13$ & $25.47 \pm 0.16$ & NS \\
\hline Egg shape index (\%) & $77.97 \pm 0.86$ & $78.39 \pm 0.59$ & $81.16 \pm 0.51$ & $80.10 \pm 1.10$ & $78.56 \pm 1.40$ & NS \\
\hline Shell weight $(\mathrm{g})$ & $1.28 \pm 0.04$ & $1.30 \pm 0.04$ & $1.21 \pm 0.05$ & $1.24 \pm 0.03$ & $1.20 \pm 0.04$ & NS \\
\hline Shell thickness (mm) & $0.23 \pm 0.00$ & $0.23 \pm 0.00$ & $0.23 \pm 0.01$ & $0.22 \pm 0.00$ & $0.22 \pm 0.00$ & NS \\
\hline \multicolumn{7}{|c|}{ Internal Egg measurements } \\
\hline Albumin height (mm) & $1.58^{\mathrm{b}} \pm 0.08$ & $1.99^{\mathrm{a}} \pm 0.10$ & $1.40^{\mathrm{b}} \pm 0.08$ & $1.44^{\mathrm{b}} \pm 0.09$ & $1.68^{b} \pm 0.11$ & $\star \star$ \\
\hline $\mathrm{HU}$ & $69.94^{\mathrm{ab}} \pm 0.7$ & $72.84^{c} \pm 0.59$ & $69.22^{\mathrm{ab}} \pm 0.88$ & $68.63^{a} \pm 0.93$ & $71.49^{b c} \pm 0.63$ & ** \\
\hline Yolk diameter (mm) & $30.34^{b} \pm 0.22$ & $30.90^{a} \pm 0.19$ & $30.02^{b} \pm 0.20$ & $30.30^{\mathrm{b}} \pm 0.11$ & $30.02^{b} \pm 0.19$ & * \\
\hline Yolk height (mm) & $9.91 \pm 0.35$ & $10.21 \pm 0.24$ & $10.55 \pm 0.22$ & $10.35 \pm 0.34$ & $9.84 \pm 0.42$ & NS \\
\hline Yolk weight $(\mathrm{g})$ & $3.58 \pm 0.18$ & $3.88 \pm 0.17$ & $3.48 \pm 0.15$ & $3.45 \pm 0.18$ & $3.50 \pm 0.16$ & NS \\
\hline Yolk index (\%) & $32.63 \pm 1.00$ & $33.02 \pm 0.66$ & $35.13 \pm 0.59$ & $34.16 \pm 1.15$ & $32.78 \pm 1.38$ & NS \\
\hline
\end{tabular}

T1= (control) birds received $100 \%$ of daily feed intake requirements,

T2= birds received $90 \%$ of daily feed intake requirements,

T3= birds received $80 \%$ of daily feed intake requirements,

T4= birds received $70 \%$ of daily feed intake requirements and

T5= birds received $60 \%$ of daily feed intake requirements.

$\mathrm{a}, \mathrm{b}, \ldots=$ Means on the same row with different letters are differ significantly $(\mathrm{P}<0.05)$

NS= insignificant differences $(P>0.05)$,

${ }^{\star *}=$ highly significant differences $(P<0.01)$

\section{Internal egg measurements:}

Obtained data on internal egg measurements at week 10 and week 14 which are in Table 6 and 7, respectively indicate that at week 10 there were significant effect on albumin height and yolk diameter. Birds received severe early life feed restriction recorded lower values of both parameters. While at week 14, these differences were disappeared.

This can only be explained by the effect of digestion and metabolic activity which may need time to reach the optimal standard level. At week 10 , these activities were probably less than at week 14. Other internal egg measurements such as yolk height, yolk weight and yolk index showed non significant $(P>0.05)$ differences among treatments in both measurable ages. In this point of view, the egg quality could not be a clear indicator for the effect of feed restriction. 
Table 7. Means \pm SE of external and internal egg quality measurements at week 14 of age for Japanese quail raised under feed restriction regimens.

\begin{tabular}{|c|c|c|c|c|c|c|}
\hline Variable & T1 & T2 & T3 & T4 & T5 & Sig. \\
\hline \multicolumn{7}{|c|}{ External Egg measurements } \\
\hline Egg weight $(\mathrm{g})$ & $10.48 \pm 0.27$ & $10.76 \pm 0.37$ & $10.63 \pm 0.32$ & $10.18 \pm 0.47$ & $11.09 \pm 0.26$ & NS \\
\hline Egg longitudinal axis (mm) & $31.16^{\mathrm{b}} \pm 0.43$ & $31.61^{\mathrm{b}} \pm 0.44$ & $31.36^{\mathrm{b}} \pm 0.38$ & $31.80^{\mathrm{b}} \pm 0.51$ & $33.30^{\mathrm{a}} \pm 0.35$ & ** \\
\hline Egg width axis (mm) & $24.81 \pm 0.22$ & $24.92 \pm 0.32$ & $25.01 \pm 0.31$ & $25.54 \pm 0.37$ & $25.73 \pm 0.28$ & NS \\
\hline Egg shape index (\%) & $79.70 \pm 1.07$ & $78.84 \pm 0.55$ & $79.82 \pm 1.29$ & $80.37 \pm 0.76$ & $77.33=$ & NS \\
\hline Shell weight $(\mathrm{g})$ & $1.63 \pm 0$ & $1.59 \pm$ & $1.50 \pm 0.05$ & $1.50 \pm 0.07$ & 1.56 & NS \\
\hline Shell thickness (mm) & $0.23 \pm 0.00$ & $0.24 \pm 0.01$ & $0.25 \pm 0.01$ & $0.24 \pm 0.01$ & $0.24 \pm$ & NS \\
\hline \multicolumn{7}{|c|}{ Internal Egg measurements } \\
\hline Albumin heigh & $2.29 \pm 0.18$ & $2.70 \pm$ & $2.82 \pm 0.13$ & $2.08=$ & $2.51 \pm$ & NS \\
\hline $\mathrm{HU}$ & $76.27 \pm 1.22$ & $78.83 \pm 1.64$ & $79.93 \pm 1.18$ & $73.81 \pm 1.78$ & $76.06 \pm$ & NS \\
\hline Yolk diameter (mm) & $23.32 \pm 0.40$ & $22.89 \pm 0.69$ & $22.79 \pm 0.42$ & $23.46 \pm 0.51$ & $25.64 \pm 0.42$ & NS \\
\hline Yolk height (mm) & $10.37 \pm 0.31$ & $10.45 \pm 0.28$ & $9.98 \pm 0.25$ & $9.47 \pm 0.27$ & $10.29 \pm 0.33$ & NS \\
\hline Yolk weight (g) & $3.42 \pm 0.08$ & $3.40 \pm 0.13$ & $3.27 \pm 0.07$ & $3.22 \pm 0.09$ & $3.63 \pm 0.08$ & NS \\
\hline Yolk index (\%) & $44.57 \pm 1.52$ & $45.80 \pm 1.04$ & $43.94 \pm 1.46$ & $40.49 \pm 1.33$ & $40.30 \pm 1.67$ & NS \\
\hline
\end{tabular}

$\mathrm{T} 1=$ (control) birds received $100 \%$ of daily feed intake requirements,

T3= birds received $80 \%$ of daily feed intake requirements,

T4= birds received $70 \%$ of daily feed intake requirements and

T5= birds received $60 \%$ of daily feed intake requirements.

$a, b, \ldots=$ Means on the same row with different letters are differ significantly $(P<0.05)$

NS= insignificant differences $(P>0.05)$,

${ }^{* *}=$ highly significant differences $(P<0.01)$

Mortality:

Numbers of dead birds during all the experiment were in normal limit and were not causing any problem in the production performance thereafter, that meaning not due to dietary treatments.

\section{Economical efficiency:}

Data presented in Table 8 , showed the economical efficiency of the experimental treatments for Japanese quail from 1 to 14 weeks of age.

The economical efficiency values for such experimental period were calculated according to the total cost (feed cost + fixed cost) and the prevailing market (selling) price of slaughtered bird, which was 3.0 LE and price of an egg, which was 0.15 LE on average at time of conducting the experiment. The total cost was declined with the increasing of restriction level. While, net revenue, economical efficiency and relative economic efficiency values were lower than the control except T2 $(90 \%$ of the recommended) which showed higher values comparing with ad lib fed group (T1).

In conclusion Using feed restriction regime at $90 \%$ daily feed intake level for Japanese quail under North Sinai conditions. 
Table 8. Economical efficiency of experimental Japanese quail hens raised under different feed restriction regimens.

\begin{tabular}{|c|c|c|c|c|c|}
\hline \multirow{2}{*}{ Item } & \multicolumn{5}{|c|}{ Treatment } \\
\hline & T1 & T2 & T3 & T4 & T5 \\
\hline \multicolumn{6}{|c|}{ From 1-6 wk of age } \\
\hline Feed intake/quail hen (Kg) & 0.69 & 0.62 & 0.55 & 0.48 & 0.41 \\
\hline Price / Kg Feed (L.E.) & 1.65 & 1.65 & 1.65 & 1.65 & 1.65 \\
\hline Cost of feed (L.E.) & 1.14 & 1.02 & 0.91 & 0.80 & 0.68 \\
\hline Fixed cost (L.E.) & 0.50 & 0.50 & 0.50 & 0.50 & 0.50 \\
\hline \multicolumn{6}{|c|}{ From 6-14 wk of age } \\
\hline Feed intake/quail hen (Kg) & 2.17 & 2.15 & 2.13 & 2.11 & 2.09 \\
\hline Price / Kg Feed (L.E.) & 1.51 & 1.51 & 1.51 & 1.51 & 1.51 \\
\hline Cost of feed (L.E.) & 3.28 & 3.25 & 3.22 & 3.19 & 3.15 \\
\hline Fixed cost (L.E.) & 0.50 & 0.50 & 0.50 & 0.50 & 0.50 \\
\hline Total costs (L.E.) & 5.42 & 5.27 & 5.13 & 4.99 & 4.83 \\
\hline Price of bird (L.E.) & 3.00 & 3.00 & 3.00 & 3.00 & 3.00 \\
\hline Egg No. / quail hen & 41.91 & 42.73 & 36.80 & 28.67 & 23.18 \\
\hline Price of egg (L.E.) ${ }^{\star}$ & 6.29 & 6.41 & 5.52 & 4.30 & 3.48 \\
\hline Total revenue (L.E ) & 9.29 & 9.41 & 8.52 & 3.30 & 6.98 \\
\hline Net revenue & 3.87 & 4.14 & 3.39 & 2.31 & 1.65 \\
\hline Economic efficiency $^{\star \star}$ & 0.71 & 0.79 & 0.66 & 0.46 & 0.34 \\
\hline Relative economic efficiency ${ }^{\star \star \star}$ & 100.00 & 111.27 & 92.96 & 64.79 & 47.89 \\
\hline
\end{tabular}

${ }^{*}$ Based upon the price of au egg which was 15 P.T

** Net revenue per unit cost.

$\star \star \star$ Assuming that the treatment number 1 represent the control.

$\mathrm{T} 1=$ (control) birds received $100 \%$ of daily feed intake requirements,

T2= birds received $90 \%$ of daily feed intake requirements,

T3= birds received $80 \%$ of daily feed intake requirements,

T4= birds received $70 \%$ of daily feed intake requirements and

T5 $=$ birds received $60 \%$ of daily feed intake requirements.

\section{REFERENCES}

Abu-Serewa, S., 1979. Response of three strains of egg-type pullets to three feed restriction regimens imposed during rearing. Aust. J. of Exp. Agric. Anim. Husb., 19:547-553.

A.O.A.C. 1990. Association of Official Analytical Chemists. Official Method of Analysis. $15^{\text {th }}$ Edition. A. O. A. C., Washington, D.C., USA.

Brody, T., Y. Eitan, M. Soller, I. Nir, and Z. Nitsan, 1980. Compensatory growth and sexual maturity in broiler females reared under severe food restriction from day of hatching. Br. Poult. Sci., 21:437-446.

Bruggeman, V., O. Onagbesan, E. D'Hondt, N. Buys, M. Safi, D. Vanmontfort, L. Berghman, F. Vandesande, and E. Decuypere. 1999. Effects of timing and duration of feed restriction during rearing on reproductive characteristics in broiler breeder females. Poultry Sci., 78:1424-1434.

Duncan, D. B. (1955). Multiple range and multiple F-tests. Biometrics. 11: 142.

Dunnington, E. A., and P. B. Siegel (1984). Age and body weight at sexual maturity in female White Leghorn chickens. Poultry Sci., 63:828-830.

Fattori, T. R, H. R. Wilson, R. H. Harms, and R. D. Miless, 1991. Response of broiler breeder females to feed restriction below recommended levels. 1. Growth and reproductive performance. Poultry Sci., 70:26-36. 
Gous, R. M., 1978. A comparison of three methods of food restriction of laying-type pullets on growth and laying performance. Br. Poult. Sci., 19:441-448.

Gous, R. M., and W. J. Stielau, 1976. Growth and laying performance of light hybrid pullets subjected to quantitative food restriction. Br. Poult. Sci., 17:487-498.

Gous, R. M.; G. D. Bradford; S. A. Johnston and T. R. Morris1(2000). Effect of age of release from light or food restriction on age at sexual maturity and egg production of laying pullets. British poultry Science, 41: 263271

Hassan SM; M.E. Mady ; A.L. Cartwright; H.M. Sabri; M.S. Mobarak (2003). Effect of early feed restriction on reproductive performance in Japanese quail (Coturnix coturnix japonica). Poult Sci. 82(7):1163-9

Hocking, P. M., 1993. Effects of body weight at sexual maturity and the degree and age of restriction during rearing on the ovarian follicular hierarchy of broiler breeder females. Br. Poult. Sci., 34:793-801.

Johansson I. and J. Randel (1968). Genetics and Animal Breeding. Oliver \& Boyed, Ltd Edinburg.

Katanbaf, M. N., E. A. Dunnington, and P. B. Siegel, 1989b. Restricted feeding in early and late-feathering chickens. 2. Reproductive response. Poultry Sci., 68:352-358.

Kostal, L., C. J. Savory and B. O. Hughes, (1992) Diurnal and individual variation in behaviour of restricted-fed broiler breeders. Applied Animal Behaviour Science 32, 361-374.

Kwakkel, R. P., B. J. Ducro, and W. J. Koops, 1993. Multiphasic analysis of growth of the body and its chemical components in White Leghorn pullets. Poultry Sci., 72:1421-1432.

Lee, P. J. W.; A. L. Gulliver, and T. R. Morris, (1971). A quantitative analysis of the literature concerning the restricted feeding of growing pullets. British Poultry Science, 12: 413-437.

Mbugua, P. N., and D. L. Cunningham, 1983. Effects of feed restriction on productive performance of replacement pullets. Poultry Sci., 62:11691176.

Morris, T. R. (1985). The manipulation of egg size and egg quality. South African Journal of Animal Science, 15: 120-122.

NRC. 1994. Nutrient Requirement of Poultry. $9^{\text {th }}$ rev. Edition. National Academy Press, Washington, DC.

SAS Institute, 1990. SAS/STAT® Guide for Personal Computers. Version 6.03 Edition. SAS Institute Inc., Gary, NC.

Savory, C. J., E. Seawright, and A. Watson, (1992). Stereotyped behaviour in broiler breeders in relation to husbandry and opioid receptor blockade. Applied Animal Behaviour Science 32, 349-360.

Sharp, P. F. (1929). U.S. Egg poultry Mag., 35(6): 14-17 c.

Silversides, F. G. (1994). Is the Haugh unit correction for egg weight valid for eggs stored at room temperature. Poultry science, 73:50-55. 


\section{Ali, A. M. et al}

Zelenka, D. J., D. E. Jones, E. A. Dunnington, and P. B. Siegel, 1987. Selection for body weight at eight weeks of age. Comparisons between mature and immature pullets at the same live weight and age. Poultry Sci., 66:41-46.

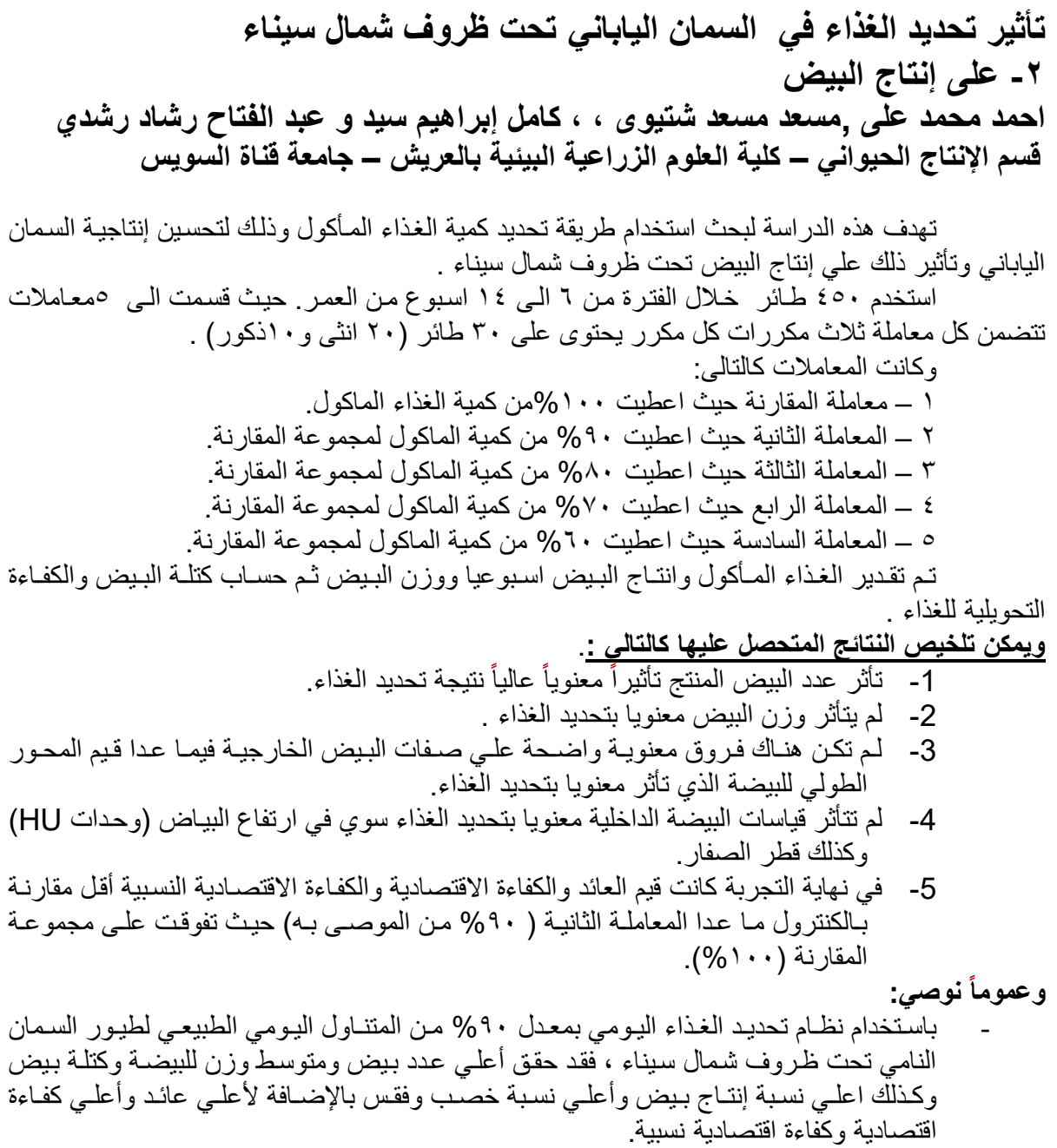

